\title{
Big issue research
}

Your letter (p. 197) asks 'where is the research engaging with the big issues that ought to be concerning the profession?'. Concluding, you ask 'Couldn't the level of thinking and analysis applied to exquisite garden sheds in the pages of arq be applied to such bigger things that are affecting the lives of millions of people ...? And if such work is already being done let everyone hear about it ...'

Much of the answer to your question can be found in the letter, from John Worthington, that follows yours (pp. 197-199) As he observes, the architectural profession 'has been weak in engaging with its academic base and investing in research ... the profession as a whole has shown very little inclination to invest either its time or money in supporting research projects ...'

It hasn't always been like this. In the years when (admittedly often inefficient) public sector building programmes dominated the economy, appropriate research was funded, undertaken, implemented and widely disseminated through the BRE, the various Ministry development groups and the formidable output of the then dominant Architects' Journal. Even in the 8os leading practitioners were willing to share their knowledge and there were valuable research projects between local authority architects and academics (but see pp. 244-261 and Sunand's work on pp. 263-279 in this issue). Moreover, until the late 80 s, there was the advertising revenue that enabled this work to be published at length in a clear and attractive way.

No longer. Today, ministers and ministries, advisors and initiatives come and go. Outside, in the real world, competition and specialisation rule. With few exceptions, competing firms and research sponsors retain rather than share knowledge; competing journals (and the web) strive to gain the architect's attention with glossy illustrations and minimal text; and competing universities may choose to distort their research programmes and teaching abilities in order to gain higher RAE ratings and better funding. Specialisation is often the outcome - and, while this may have benefits in the world of practice, it is all too often nothing short of a disaster for architectural education and, ultimately, architecture.

Over the past nine years, arq has, uniquely, pursued a policy of publishing in depth across the full range of architectural endeavour. With minimal resources, we have tried our best - against the forces of specialisation - to demonstrate the full range of architectural research. We may not have picked up the big issues but that is because such research is generally unavailable. But we all agree it's needed. So, why don't CABE and a 'club' of responsible practices pick up John Worthington's challenge and get together with some university departments (architecture, planning, business studies, land economy and so on) to undertake big issue research?

Richard Weston and arq 's new Editorial team (p. 202) would welcome the opportunity to edit and publish such work. 